DOI: $10.20472 /$ TEC.2017.004.005

\author{
MAJA GLOGOVAC \\ Faculty of organisational sciences, Yugoslavia \\ MARIJA KRASIC \\ Faculty of organisational sciences, Yugoslavia \\ ALEKSA VULOVIC \\ Faculty of organisational sciences, Yugoslavia \\ ZORAN RAKICEVIC \\ Faculty of organisational sciences, Yugoslavia \\ ANA HORVAT \\ Faculty of organisational sciences, Yugoslavia
}

\title{
IMPORTANCE OF SPECIFIC RISKS IN HIGHER EDUCATION
}

\begin{abstract}
:
Taking the increasing importance of risk-based thinking and importance of education into consideration, this paper aims at pointing out the rank of risks in higher education institution (HEI) according to their importance. Additionally, the paper aims at identifying best methods for avoiding these risks. This can help HEl to identify risks in order to improve their teaching process by using best methods. Since teaching process was observed as the main process of higher education institutions, we conducted the questionnaire to establish the rank of risks according to their importance from the student's point of view. Using t-test and SPSS software, we got three most important risks: low quality of lectures, imbalanced criteria on exams (too strong or too weak), and non-use of technology and modern equipment while teaching. Also, it is proven in this paper that there are differences in ranking risks' importance between students from developed and developing countries, as well as between male and female students. When we observed students' year of study and their average grade, we also found differences in ranking risks' importance.
\end{abstract}

\section{Keywords:}

Risks; Importance; Higher Education Institutions (HEI); Measures; Teaching process; Students

JEL Classification: A00 


\section{Introduction}

The Higher Education Institutions (HEI) have their purpose which is to accomplish all demands of education and professional training and to fulfill requirements of a community. HEl fulfill this purpose in order to set a standard for individuals and society to be in the best possible environment (Petrescu et al., 2015, p.23). On the primary elements of any HEI such as benefits of academic quality, research, and curriculum, developing countries pay more attention (Knight, 2007, p. 60). According to Janovac (2014, p.65), business environment of $\mathrm{HEl}$ is completely different today compared to the period before 10 or 20 years. Accordingly, there are more threats for increasing risk exposure of HEI. Today, it is impossible to imagine company management without risk management based on the risks to which the company is exposed. The risk management in each process allows for greater possibilities for its successful implementation. A company which incorporates the risk management into a management system can achieve better results and make more rational strategic decisions (Ruzic-Dimitrijevic \& Dakic, 2014, p138).

As it is stated in ISO 9001:2015, „risk-based thinking enables an organization to determine the factors that could cause its processes and its quality management system to deviate from the planned results, to put in place preventive controls to minimize negative effects and to make maximum use of opportunities as they arise". So, ISO 9001 elements should be put from dedication to customer and their requirements to fulfillment of those requirements (Karapetrovic et al., 1998, p. 105). „Risk is the effect of uncertainty, and any such uncertainty can have positive or negative effects. A positive deviation arising from a risk can provide an opportunity, but not all positive effects of risk result in opportunities"(SRPS ISO 9001:2015, p. 15). Risk includes uncertainty and undesirability, so the risk is a potential harm to human health, their property and environment (Helsloot \& Jong, 2006, p. 143). There should be explicit boundaries of behaviour in the organisation in order to prevent deviations (Rasmussen, 1997, p. 191).

The most relevant tool for improving processes and procedures is the reason for the implementation of QMS which is related to ISO 9001(Raisiene et al., 2013, p.83). In HEI most common reasons to implement quality management system (QMS) are the opportunity to improve internal processes and procedures of the institution and to improve management, performance and effectiveness (Raisiene et al., 
2013 , p.83). In order to understand the worth of risks and their relation with $\mathrm{HEI}$, they should establish a culture of risk management. Risks have to be identified, estimated and managed (Berg, 2010, p. 81).

Most processes have internal and external sources of the risk, and all of them should be considered, and the risks, dangers, and possible consequences must be identified for each process (Ruzic-Dimitrijevic \& Dakic, 2014, p142). At the same time, certain processes are of greater or lesser significance for the company. So, the significance should be added to the risks to which they are exposed. Taking this into consideration, as well as the importance of risk-based thinking for HEl today, this paper aims at boosting knowledge about the importance of specific risks HEI related.

\section{Research methodology}

\subsection{Aim of research}

The aim of this research is to rank risks in HEl according to their importance from the students' point of view. Based on other research in this field (e.g. Ruzic-Dimitrijevic \& Dakic, 2014), we find teaching process as the main source of such risks in HEl. Additionally, this research aims at identifying best methods for avoiding those risks. This can help HEI to identify risks in order to improve their teaching process by using the most effective measures.

\subsection{Research questions and hypotheses}

Although the percentage of higher educated persons in Europe is greater than before (EurActiv, 2015), business environment of HEI is completely different today compared to the period before 10 or 20 years (Janovac, 2014 , p.65). At the same time, the HEI are seen as an important factor in fulfilling requirements of community in order to set a standard for individuals and society to be in the best possible environment (Petrescu et al., 2015, p.23). In line with this, we defined the first hypothesis of the research:

Hypothesis $\mathrm{H} 1$ - Low quality of teaching process is the most important risk in HEI 
On the other hand, there is no enough research about the importance of different risks in the available literature. Taking this into consideration, we defined the following research question:

Research question Q1 - Which are the most important risks in HEI?

Since developing countries pay more attention to the primary elements of $\mathrm{HEI}$ such as benefits of academic quality, research, and curriculum (Knight, 2007, p. 60), we supposed the following hypothesis:

Hypothesis H2 - There is statistically significant difference in risks' importance ranking between participants from developing countries and participants from developed countries.

On the other hand, considering that education should have an equal impact and importance for each person, no matter of his/her characteristics, the following three hypotheses are also defined:

Hypothesis $\mathrm{H} 3$-There is no statistically significant difference between students with different average grade in ranking risks' importance

Hypothesis H4 -There is no statistically significant difference between students at different study year in ranking risks' importance

Hypothesis H5 -There is no statistically significant difference between male and female students in ranking risks' importance

In addition, we put an effort to enrich some conclusions about the improvement of the teaching process, so we wanted to identify measures for avoiding the most important risks. This yielded the following research question.

Research question Q2- Which measures are the most effective for avoiding risks and improving teaching process?

\subsection{Population and sample characteristics}

The population of this research are students from HEI, from both developing and developed countries worldwide. Students are chosen as target group because they directly participate in the teaching process realisation. The questionnaire was sent to 100 random selected potential participants, where 52 of them give usable answers. This means the response rate is slightly higher than $50 \%$. The sample consists of male and female students (there are more female than male participants) who are in different fields of study (most of them are studying management 
and economy, but also significant number of them are studying information technology, technical science and medicine), from developing and developed countries (there are more participants from developing than developed countries) on different year of study (there is slight difference in number of students on first\&second year and third,fourth\&master).

\section{Figure 1. Sample characteristics}

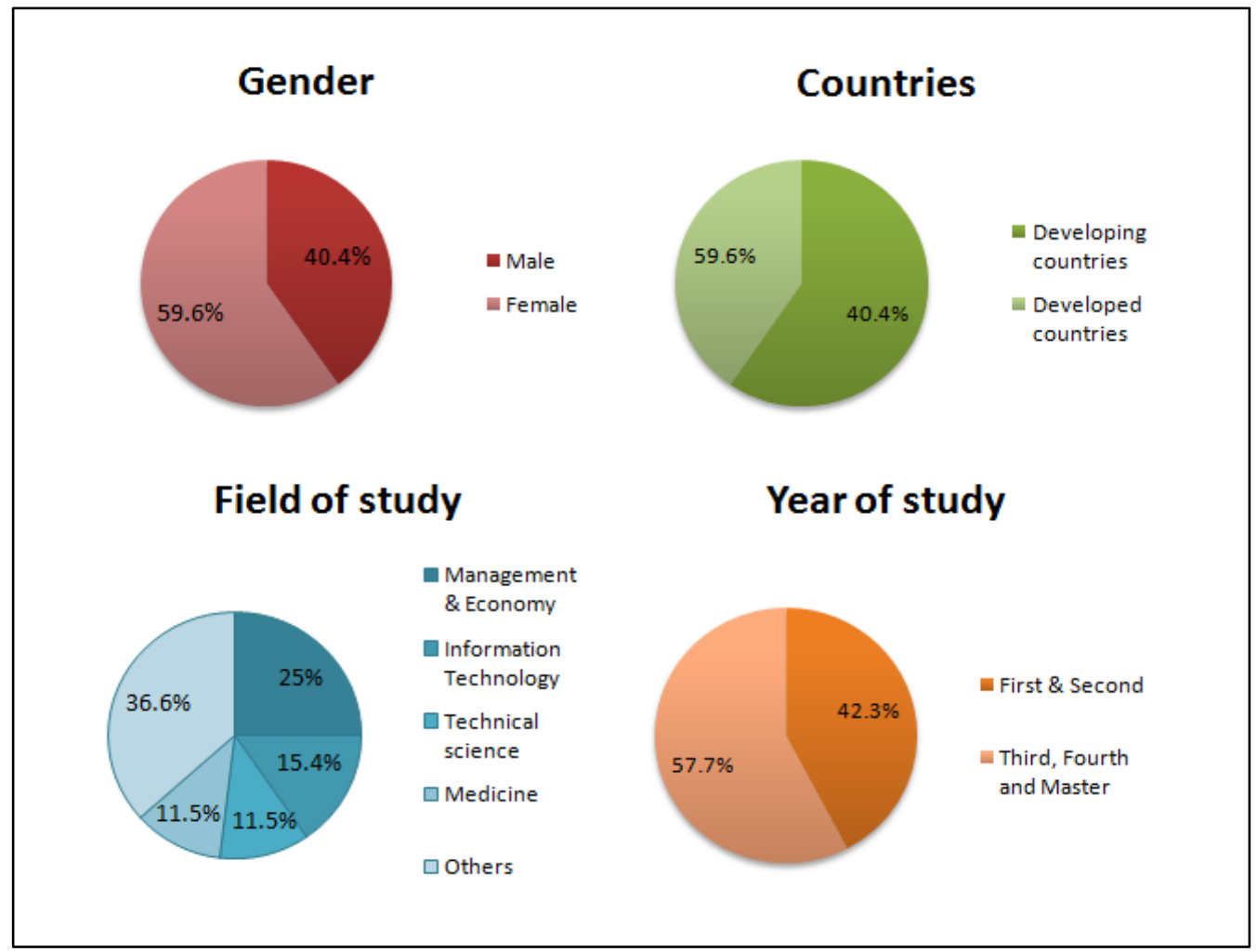

\subsection{Research instrument}

We used questionnaire consisted of two parts in order to perform the research. The first part is related to sample characteristics, which includes: gender, the country they study in, year of study, the field of study and average grade. The second part is related to rating importance of defined risks on a scale from 1 (extremely unimportant) to 5(extremely important). Those risks are related to teaching process, and they are identified in accordance with risks list presented in Table 1. Possible measures for avoiding those risks are also presented in the same table. 
Table 1. Categories of risks in HEI and measures for avoiding them

\begin{tabular}{|c|c|c|c|}
\hline Categories & Risks & $\begin{array}{l}\text { Possible } \\
\text { consequences }\end{array}$ & Measures \\
\hline \multirow{2}{*}{ 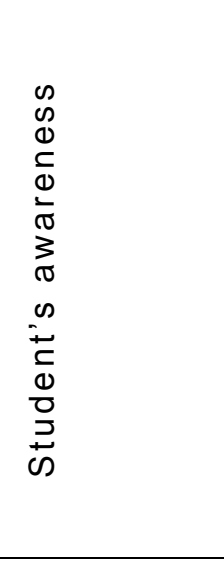 } & $\begin{array}{l}\text { Low awareness } \\
\text { of students' } \\
\text { rights and } \\
\text { obligations }\end{array}$ & \multirow[t]{2}{*}{$\begin{array}{l}\text { Students' } \\
\text { dissatisfaction; } \\
\text { Further spreading } \\
\text { of bad } \\
\text { experience; Bad } \\
\text { school reputation }\end{array}$} & $\begin{array}{l}\text { Anticipate periodical meetings } \\
\text { between directors of study } \\
\text { groups and students; Regular } \\
\text { advertising and informing of } \\
\text { students through the notice- } \\
\text { boards and school website }\end{array}$ \\
\hline & $\begin{array}{l}\text { Students' bad } \\
\text { communication } \\
\text { with teachers }\end{array}$ & & $\begin{array}{l}\text { Hold periodical meetings } \\
\text { between professors and } \\
\text { students; Making behavior } \\
\text { codex }\end{array}$ \\
\hline \multirow{3}{*}{ 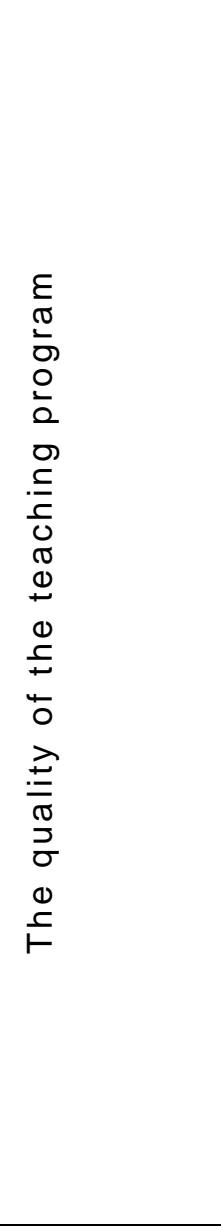 } & $\begin{array}{l}\text { Absence of a } \\
\text { teachers' good } \\
\text { communication } \\
\text { with students }\end{array}$ & \multirow[t]{3}{*}{$\begin{array}{l}\text { Dissatisfaction; } \\
\text { Bad experience of } \\
\text { the students; Loss } \\
\text { of school } \\
\text { reputation; Low } \\
\text { enrollment rate }\end{array}$} & $\begin{array}{l}\text { Making behavior codex; } \\
\text { Assessment of the teacher's } \\
\text { work and corrections concerning } \\
\text { that issue; Giving punishment } \\
\text { for teachers from executive } \\
\text { board; Hiring the highest quality } \\
\text { teaching staff }\end{array}$ \\
\hline & $\begin{array}{l}\text { Low quality of } \\
\text { lectures }\end{array}$ & & $\begin{array}{l}\text { Encourage students to think, } \\
\text { with examples from good } \\
\text { practice; Using of modern } \\
\text { technology; Equal exposure of } \\
\text { theory and practice; Internal } \\
\text { inspection; Surveying students } \\
\text { for quality of lectures; Training } \\
\text { teachers; Hiring the highest } \\
\text { quality teaching staff }\end{array}$ \\
\hline & $\begin{array}{l}\text { Imbalanced } \\
\text { criteria on } \\
\text { exams (too } \\
\text { strong or too } \\
\text { weak) }\end{array}$ & & $\begin{array}{l}\text { Assessment of the teacher's } \\
\text { work and corrections concerning } \\
\text { that issue; Making evaluation } \\
\text { rules for conducting exams; } \\
\text { Hiring the highest quality } \\
\text { teaching staff }\end{array}$ \\
\hline 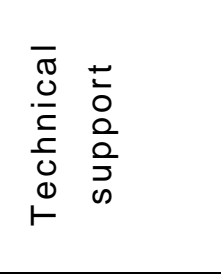 & $\begin{array}{l}\text { Non-existence } \\
\text { of } \\
\text { contemporary } \\
\text { devices and } \\
\text { electronic }\end{array}$ & $\begin{array}{l}\text { Bad experiences } \\
\text { of students; } \\
\text { School reputation; } \\
\text { Low enrollment } \\
\text { rate }\end{array}$ & Acquisition of the equipment \\
\hline
\end{tabular}




\begin{tabular}{|c|c|c|c|}
\hline & means & & \multirow[b]{2}{*}{ Continual training of teachers } \\
\hline & $\begin{array}{l}\text { Non-use of } \\
\text { contemporary } \\
\text { devices and } \\
\text { electronic } \\
\text { means }\end{array}$ & & \\
\hline \multirow{3}{*}{ 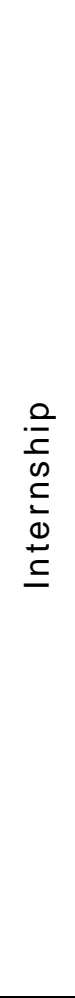 } & $\begin{array}{l}\text { Bad choice of } \\
\text { companies in } \\
\text { terms of the } \\
\text { activity and } \\
\text { process }\end{array}$ & \multirow{3}{*}{$\begin{array}{l}\text { Bad experience of } \\
\text { students; Bad } \\
\text { experience of } \\
\text { associates from } \\
\text { the economy, } \\
\text { which jeopardises } \\
\text { school reputation }\end{array}$} & $\begin{array}{l}\text { Inform students about the } \\
\text { practice and the possible } \\
\text { companies; Engagement of } \\
\text { teachers in searching for an } \\
\text { appropriate company }\end{array}$ \\
\hline & $\begin{array}{l}\text { Teacher and } \\
\text { co-mentor from } \\
\text { the company } \\
\text { exhibits bad } \\
\text { cooperation }\end{array}$ & & $\begin{array}{l}\text { Achieve good communication } \\
\text { between teacher who follows } \\
\text { the work of a student and } \\
\text { mentor; Weekly report from } \\
\text { students on internship }\end{array}$ \\
\hline & $\begin{array}{l}\text { Student is } \\
\text { irresponsible to } \\
\text { his obligation } \\
\text { during practice } \\
\text { or failed to } \\
\text { express } \\
\text { expected } \\
\text { knowledge }\end{array}$ & & $\begin{array}{l}\text { Testing students before sending } \\
\text { them on internship; Weekly } \\
\text { report from company }\end{array}$ \\
\hline
\end{tabular}

Source: adapted from Ruzic-Dimitrijevic \& Dakic, 2014, p144

\section{Data Analysis Methods}

In order to test the hypotheses, we conducted two statistical tools:

1. One-Sample t-test for establishing the rank of risks in teaching process;

2. Independent Sample t-test for founding statistical differences in giving importance to risks in relation to countries, year of study, average grade and gender of students. If the value $p$ is less than 0.05 , then there is the difference between testing groups. 


\subsection{Results}

The first research question is related to finding the most important risks. After the data analysis, all of the risks are ranked according to mean values, as it is shown in Table2. The most important three risks are low quality of lectures, imbalanced criteria on exams (too strong or too weak), and non-use of technology and modern equipment while teaching. At the same time, we proven hypothesis $\mathrm{H} 1$ as true since Low quality of lectures (Mean=4,288) is shown to be the most important risk.

\section{Table2. The rank of risks in HEI according to their importance}

\begin{tabular}{|l|l|l|}
\hline One-Sample Statistics & Mean & Std. Deviation \\
\hline Risks & 4.288 & $\mathbf{0 . 9 5 7}$ \\
\hline Low quality of lectures & 3.981 & $\mathbf{1 . 0 3 8}$ \\
\hline Imbalanced criteria on exams (too strong or too weak) & $\mathbf{3 . 9 8 1}$ & $\mathbf{1 . 1 1 1}$ \\
\hline $\begin{array}{l}\text { Non-use of technology and modern equipment while } \\
\text { teaching }\end{array}$ & 3.942 & 1.127 \\
\hline $\begin{array}{l}\text { Student is irresponsible to his obligation during practice or } \\
\text { failed to express expected knowledge }\end{array}$ & 3.923 & 1.026 \\
\hline Student's bad communication with teachers & 3.923 & 1.063 \\
\hline Absence of a teachers' good communication with students & 3.885 & 1.149 \\
\hline $\begin{array}{l}\text { Non-existence of technology and modern equipment while } \\
\text { teaching }\end{array}$ & 3.712 & 0.936 \\
\hline Low students awareness of their rights and obligations & 3.615 & 1.223 \\
\hline Bad choice of companies for internship & 3.519 & 1.129 \\
\hline Mentor from the internship company exhibits bad cooperation & & \\
\hline
\end{tabular}

When it comes to differences in risk importance between students from developed $(M=4.48, \quad S D=0.680)$ and developing countries $(M=4.48$, $\mathrm{SD}=0.680$ ), Table3 shows that the difference exists for Imbalanced criteria on the exam, as one of the observed risks. 
Table3. Differences in risk importance between students from developed and developing countries

\begin{tabular}{|c|c|c|c|c|c|c|c|c|}
\hline \multicolumn{9}{|l|}{ Independent Samples Test } \\
\hline & \multicolumn{2}{|c|}{$\begin{array}{l}\text { Levene's } \\
\text { Test for } \\
\text { Equality of } \\
\text { Variances }\end{array}$} & \multicolumn{6}{|c|}{ t-test for Equality of Means } \\
\hline & \multirow[t]{2}{*}{$\mathrm{F}$} & \multirow[t]{2}{*}{$\begin{array}{l}\text { Sig. } \\
\text { "p" }\end{array}$} & \multirow[t]{2}{*}{$\mathrm{t}$} & \multirow[t]{2}{*}{ df } & \multirow[t]{2}{*}{$\begin{array}{l}\text { Mean } \\
\text { Difference }\end{array}$} & \multirow[t]{2}{*}{$\begin{array}{l}\text { Std. Error } \\
\text { Difference }\end{array}$} & \multicolumn{2}{|c|}{$\begin{array}{l}95 \% \\
\text { Confidence } \\
\text { Interval of the } \\
\text { Difference }\end{array}$} \\
\hline & & & & & & & Lower & Upper \\
\hline $\begin{array}{l}\text { Imbalanced criteria on exams } \\
\text { (too strong or too weak) }\end{array}$ & 5.371 & 0.025 & 3.054 & 50.000 & 0.831 & 0.272 & 0.285 & 1.377 \\
\hline
\end{tabular}

Imbalanced criteria on exams (Table 4) is also risk for which there is difference in importance between students with different average grade (below 8.00: $M=3.65, S D=1.268$ and above 8.01: $M=4.19, S D=0.821$ ).

Table4. Differences in risk importance between students with different average grade

\begin{tabular}{|c|c|c|c|c|c|c|c|c|}
\hline \multicolumn{9}{|c|}{ Independent Samples Test } \\
\hline & \multicolumn{2}{|c|}{$\begin{array}{l}\text { Levene's Test } \\
\text { for Equality of } \\
\text { Variances }\end{array}$} & \multicolumn{6}{|c|}{ t-test for Equality of Means } \\
\hline & \multirow[t]{2}{*}{$\mathrm{F}$} & \multirow[t]{2}{*}{$\begin{array}{l}\text { Sig. } \\
\text { "p" }\end{array}$} & \multirow[t]{2}{*}{$\mathrm{t}$} & \multirow[t]{2}{*}{ df } & \multirow{2}{*}{$\begin{array}{l}\text { Mean } \\
\text { Differe } \\
\text { nce }\end{array}$} & \multirow[t]{2}{*}{$\begin{array}{l}\text { Std. Error } \\
\text { Difference }\end{array}$} & \multicolumn{2}{|c|}{$\begin{array}{l}95 \% \text { Confidence Interval } \\
\text { of the Difference }\end{array}$} \\
\hline & & & & & & & Lower & Upper \\
\hline $\begin{array}{l}\text { Imbalanced criteria } \\
\text { on exams } \\
\text { (too strong or too } \\
\text { weak) }\end{array}$ & 5.359 & 0.025 & -1.859 & 50.000 & -0.538 & 0.289 & -1.118 & 0.043 \\
\hline
\end{tabular}

When it comes to difference between students at different study year in ranking risks' importance, for students on first\&second year risks' mean value and standard deviations are: Bad choice of companies for internship $(M=3.41, S D=1.403)$; Student is irresponsible to his obligation during practice or failed to express expected knowledge $(M=3.77$, 
$S D=1.343)$; Non-use of technology and modern equipment while teaching $(M=3,68, S D=1.287)$. For students on third, fourth\&master, mean value and standard deviations are: Bad choice of companies for internship $(\mathrm{M}=3.77, \mathrm{SD}=1.073)$; Student is irresponsible to his obligation during practice or failed to express expected knowledge $(M=4.07, S D=0.944)$; Non-use of technology and modern equipment while teaching $(M=4.20$, $S D=0.925)$.

Table5. Differences in risk importance between students at different study year

\begin{tabular}{|l|l|l|l|l|l|l|l|l|}
\hline \multicolumn{2}{|l|}{ Independent Samples Test } \\
\hline & $\begin{array}{l}\text { Levene's Test } \\
\text { for Equality of } \\
\text { Variances }\end{array}$ & \multicolumn{2}{l|}{ t-test for Equality of Means } \\
\cline { 2 - 10 } & F & $\begin{array}{l}\text { Sig. } \\
\text { "p" }\end{array}$ & t & df & \multicolumn{2}{l|}{$\begin{array}{l}\text { Mean } \\
\text { Differe } \\
\text { nce }\end{array}$} & $\begin{array}{l}\text { Std. } \\
\text { Error } \\
\text { Differe } \\
\text { nce }\end{array}$ & $\begin{array}{l}\text { 95\% Confidence } \\
\text { Interval of the } \\
\text { Difference }\end{array}$ \\
\hline $\begin{array}{l}\text { Bad choice of companies for } \\
\text { internship }\end{array}$ & 4.178 & 0.046 & -1.042 & 50.000 & -0.358 & 0.343 & -1.047 & 0.331 \\
\hline $\begin{array}{l}\text { Student is irresponsible to his } \\
\text { obligation during practice or } \\
\text { failed to express expected } \\
\text { knowledge }\end{array}$ & 4.125 & 0.048 & -0.928 & 50.000 & -0.294 & 0.317 & -0.930 & 0.343 \\
\hline $\begin{array}{l}\text { Non-use of technology and } \\
\text { modern equipment while } \\
\text { teaching }\end{array}$ & 5.806 & 0.020 & -1.691 & 50.000 & -0.518 & 0.306 & -1.134 & 0.097 \\
\hline
\end{tabular}

Table6 shows the difference between male $(M=3.24, S D=1.411)$ and female $(M=3.71, S D=0.864)$ students in the ranking importance of Mentor from the internship company exhibits bad cooperation. 
Table6. Differences in risk importance between male and female students

\begin{tabular}{|c|c|c|c|c|c|c|c|c|}
\hline \multicolumn{9}{|l|}{ Independent Samples Test } \\
\hline & \multicolumn{2}{|c|}{$\begin{array}{l}\text { Levene's Test } \\
\text { for Equality of } \\
\text { Variances }\end{array}$} & \multicolumn{6}{|c|}{ t-test for Equality of Means } \\
\hline & \multirow[t]{2}{*}{$\mathrm{F}$} & \multirow[t]{2}{*}{$\begin{array}{l}\text { Sig. } \\
\text { "p" }\end{array}$} & \multirow[t]{2}{*}{$\mathrm{t}$} & \multirow[t]{2}{*}{ df } & \multirow[t]{2}{*}{$\begin{array}{l}\text { Mean } \\
\text { Differe } \\
\text { nce }\end{array}$} & \multirow{2}{*}{$\begin{array}{l}\text { Std. } \\
\text { Error } \\
\text { Differe } \\
\text { nce }\end{array}$} & \multicolumn{2}{|c|}{$\begin{array}{l}95 \% \text { Confidence } \\
\text { Interval of the } \\
\text { Difference }\end{array}$} \\
\hline & & & & & & & Lower & Upper \\
\hline $\begin{array}{l}\text { Mentor from the internship } \\
\text { company exhibits bad } \\
\text { cooperation }\end{array}$ & 7.738 & 0.008 & -1.496 & 50.000 & -0.472 & 0.315 & -1.105 & 0.162 \\
\hline
\end{tabular}

The additional research analysis is related to finding most effective measures for avoiding the most important risks and improving teaching process. As it is shown on Figure1, for the low quality of lectures, the most effective measure is found to be Encouraging students to think with examples from good practice. As it can be seen on Figure2, Making evaluation rules for conducting exams is seen as the most effective measure for avoiding imbalanced criteria on exams. For non-using of technology and modern equipment while teaching, the only recognised measure is the continual teaching of teachers.

\section{Figure1. Measures for low quality of lectures}

\begin{tabular}{|c|c|c|c|c|}
\hline Low quality \\
of lectures
\end{tabular}




\section{Figure2. Measures for imbalanced criteria on exams (too strong or too weak)}

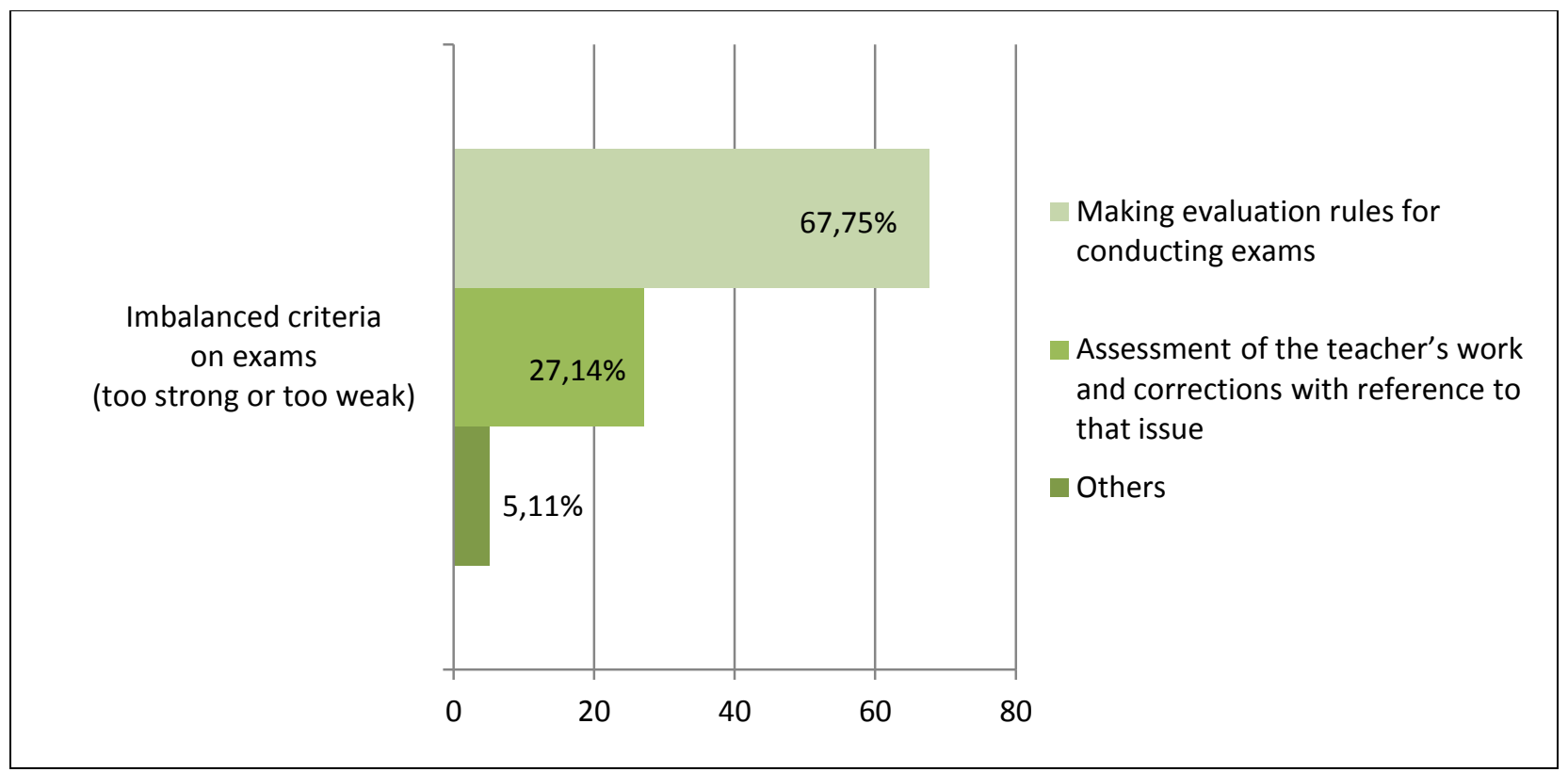

\section{Conclusion and Discussion}

Considering new version of standard ISO 9001:2015 which points out the importance of risk-based thinking as well as the lack of literature in the field of risks in $\mathrm{HEI}$, we decided to conduct research in the field of risks in $\mathrm{HEl}$. Actually, we defined the specific risks in $\mathrm{HEI}$ in accordance with the available research in this field in order to select the most important risks which HEl should work on to improve their processes. Students, as one of the most important interested parties of $\mathrm{HEI}$, are used as a target group for the research (sample of 52 students) because they directly participate in the teaching process realisation. In this research, students recognised three most important risks which can disrupt the quality of teaching process. In addition, students identified the most effective measures for avoiding each risk.

As the most important risk of teaching process is shown to be low quality of lectures, that is because that risk can have a huge impact on the satisfaction of students. This is also in line with the importance of $\mathrm{HEI}$ quality generally. Such results proved hypothesis $\mathrm{H} 1$ as true. When it comes to the research question Q1, we concluded that three most important risks in $\mathrm{HEI}$ are: low quality of lectures, imbalanced criteria on exams (too strong or too weak), and non-use of technology and modern equipment while teaching. Imbalanced criteria on exams (too strong or 
too weak) has been identified as a risk for which there is difference in ranking its' importance between students from developed and developing countries, and among students with the different average grade. The most effective measure for avoiding this risk is found to be making evaluation rules for conducting exams, in order to find compromised criteria for exams. Such results show that hypotheses $\mathrm{H} 2$ and $\mathrm{H} 3$ could not be accepted as true. Also, students on a different year of the study showed the difference in ranking the importance of bad choice of companies for an internship as a risk. Thus it should be explained and shown to students on the lower year of study (first and second) what is the importance of an adequate choosing a company in terms that it could have an impact on their future professional growth. Considering this result, we proved hypothesis $\mathrm{H} 4$ also as not true.

Although we assumed there would not be differences in ranking risks' importance between male and female students, it is shown that there is the difference and it refers to the risk that mentor from the internship company exhibits bad cooperation. We think that it could be because of the different point of view and expectations. Students pointed out encouraging students to think, with examples from good practice as a most effective measure for avoiding this risk. So, we can conclude that students need motivation and continual encouraging to think. In line with this, professors should frequently use good examples from practice and motivate students to think and boost their knowledge.

It is of great importance for $\mathrm{HEI}$ to define risks and rank their importance in order to initiate an adequate preventive measure for avoiding those risks and make their processes of better and better quality.

\section{References}

BERG,H. P. (2010) Risk Management: Procedures, Methods and Experiences. Risk Management. 2010, Vol. 17, No. 1, s. 79-95.

EURACTIV, Retrieved on 2016, November 11 from http://www.euractiv.rs/srbija-ieu/8607-raste-procenat-visokoobrazovanih

HELSLOOT, I; and JONG, W. (2006) Risk Management in Higher Education and Research in the Netherlands. Journal of Contingencies and Crisis Management. 2006, Vol. 14, No. 3, s. 142-159. 
JANOVAC, D., T.. (2014) Improving the Quality of Higher Education Institutions on the basis of the of needs of customers as a criteria. Belgrade: Faculty of Applied Management, Economics and Finance, PhD thesis, 2014.

KARAPETROVIC, S.; RAJAMANI, D. and WILLBORN, W. (1998) ISO 9001 Quality System: An Interpretation for the University. Int. J. Engineering Education, 1998, Vol. 14, No. 2, s. 105-118.

KNIGHT, J. (2007) Internationalization Brings Important Benefits as Well as Risks. International Higher Education, the Quarterly publication of the Boston College Center for International Higher Education, Num. 46, Winter 2007, s.59-62.

Petrescu, I.; NeAgoe, M.; StAnCiU, S.; JALIU, C.; I., RADUlescu, C. and GOGU, E.. (2015) Summary Report on Trends in the Evolution of Quality in Higher Education Following the Assessments Made. The Romanian Agency for Quality Assurance in Higher Education, 2015.

RAISIENE, A.,G. (2013) Social Transformations in Contemporary Society. Proceedings of an Annual International Conference for Young Researchers, ISSN 2345-0126 (online)

RASMUSSEN, J. (1997) Risk Management in a Dynamic Society: A Modelling Problem. Safety Science. 1997, Vol. 27, No. 2/3, s. 183-213.

RUZIC-DIMITRIJEVIC, Lj. and DAKIC, J. (2014) The Risk Management in Higher Education Institutions. 2014, Online Journal of Applied Knowledge Management, Vol. 2, No. 1, s. 137-152.

SRPS ISO 9001:2015 - Quality Management Systems - Requirement, International Organization for Standardization, 2015. 